U.S. Government Accountability Office

\title{
FramewORK
}

\author{
FOR
}

\section{Assessing THE}

\section{ACQUISITION FunCTION at Federal Agencies}

September 2005 



\section{PREFACE}

Federal agencies are relying increasingly on contractors to perform their missions. With hundreds of billions of tax dollars spent each year on goods and services, it is essential that federal acquisition be handled in an efficient, effective, and accountable manner. The Government Accountability Office (GAO), however-as well as other accountability organizations, inspectors general, and the agencies themselves - continue to identify systemic weaknesses in key areas of acquisition. In fact, the acquisition function at several agencies has been on GAO's high-risk list, which identifies areas in the federal government with greater vulnerability to fraud, waste, abuse, and mismanagement. In January 2005, we added interagency contracting to this list.

Far too often, the result of poor acquisitions has been an inability to obtain quality goods and services on time and at a fair price. We can no longer afford such outcomes. Given current fiscal demands and the fiscal challenges we are likely to face in the 21 st century, the federal government must improve its ability to acquire goods and services in a cost-effective manner.

GAO developed this framework to enable high-level, qualitative assessments of the strengths and weaknesses of the acquisition function at federal agencies. Such assessments can

$\checkmark$ help senior agency executives identify areas needing greater management attention, and

$\checkmark$ enable accountability organizations (including GAO) to identify areas requiring more focused follow-up work.

The framework consists of four interrelated cornerstones that our work has shown are essential to an efficient, effective, and accountable acquisition process: (1) organizational alignment and leadership, (2) policies and processes, (3) human capital, and (4) knowledge and information management. The framework supports an integrated evaluation approach, but each of these cornerstones can stand alone so users of this framework may tailor evaluations to an agency's specific needs. The table on page iii provides an overview of the framework. Using the table, readers can see at a glance how the framework is structured and can quickly identify specific areas that may be of interest.

In developing the framework, GAO consulted with federal government and industry experts in the areas of human capital, information management, financial management, and acquisition practices. Additionally, we drew upon decades of experience within GAO in reviewing each of these areas. 
We welcome any feedback you might have to enhance the usefulness of this framework. Please send comments by e-mail to frameworkcomments@gao.gov. I can also be reached at (202) 512-4841.

The framework was prepared under the direction of Bill Woods. Key contributors to this product were Lily Chin, Christina Cromley, Timothy DiNapoli, and Shannon Simpson.

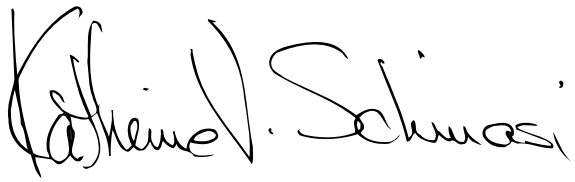

Katherine V. Schinasi

Managing Director

Acquisition and Sourcing Management 


\section{Framework for Assessing the Acquisition Function}

\begin{tabular}{|c|c|c|}
\hline Cornerstones & Elements & Critical Success Factors \\
\hline \multirow[t]{2}{*}{$\begin{array}{l}\text { Organizational } \\
\text { Alignment and } \\
\text { Leadership }\end{array}$} & $\begin{array}{l}\text { Aligning Acquisition with Agency's } \\
\text { Missions and Needs }\end{array}$ & $\begin{array}{l}\text { - Assuring Appropriate Placement of the } \\
\text { - Acquisition Function } \\
\text { Organizing the Acquisition Function to } \\
\text { Operate Strategically } \\
\text { - Clearly Defining and Integrating Roles and } \\
\text { Responsibilities }\end{array}$ \\
\hline & Commitment from Leadership & $\begin{array}{l}\text { - Clear, Strong, and Ethical Executive } \\
\text { Leadership } \\
\text { - Effective Communications and Continuous } \\
\text { Improvement }\end{array}$ \\
\hline \multirow[t]{3}{*}{$\begin{array}{l}\text { Policies and } \\
\text { Processes }\end{array}$} & Planning Strategically & $\begin{array}{l}\text { - Partnering with Internal Organizations } \\
\text { - Assessing Internal Requirements and the } \\
\text { Impact of External Events }\end{array}$ \\
\hline & $\begin{array}{l}\text { Effectively Managing the } \\
\text { Acquisition Process }\end{array}$ & $\begin{array}{l}\text { - Empowering Cross-Functional Teams } \\
\text { - Managing and Engaging Suppliers } \\
\text { - Monitoring and Providing Oversight to } \\
\text { Achieve Desired Outcomes } \\
\text { - Enabling Financial Accountability }\end{array}$ \\
\hline & $\begin{array}{l}\text { Promoting Successful Outcomes } \\
\text { of Major Projects }\end{array}$ & $\begin{array}{l}\text { - Using Sound Capital Investment Strategies } \\
\text { - Employing Knowledge-Based Acquisition } \\
\text { Approaches }\end{array}$ \\
\hline \multirow[t]{4}{*}{ Human Capital } & $\begin{array}{l}\text { Valuing and Investing in the } \\
\text { Acquisition Workforce }\end{array}$ & $\begin{array}{l}\text { - Commitment to Human Capital } \\
\text { Management } \\
\text { - Role of the Human Capital Function }\end{array}$ \\
\hline & Strategic Human Capital Planning & $\begin{array}{l}\text { - Integration and Alignment } \\
\text { - Data-Driven Human Capital Decisions }\end{array}$ \\
\hline & $\begin{array}{l}\text { Acquiring, Developing, and } \\
\text { Retaining Talent }\end{array}$ & $\begin{array}{l}\text { - Targeted Investments in People } \\
\text { - Human Capital Approaches Tailored to } \\
\text { Meet Organizational Needs }\end{array}$ \\
\hline & $\begin{array}{l}\text { Creating Results-Oriented } \\
\text { Organizational Cultures }\end{array}$ & $\begin{array}{l}\text { - Empowerment and Inclusiveness } \\
\text { - Unit and Individual Performance Linked to } \\
\text { Organizational Goals }\end{array}$ \\
\hline \multirow[t]{2}{*}{$\begin{array}{l}\text { Knowledge and } \\
\text { Information } \\
\text { Management }\end{array}$} & $\begin{array}{l}\text { Identifying Data and Technology } \\
\text { that Support Acquisition } \\
\text { Management Decisions }\end{array}$ & $\begin{array}{l}\text { - Tracking Acquisition Data } \\
\text { - Translating Financial Data into Meaningful } \\
\text { Formats } \\
\text { - Analyzing Goods and Services Spending }\end{array}$ \\
\hline & $\begin{array}{l}\text { Safeguarding the Integrity of } \\
\text { Operations and Data }\end{array}$ & $\begin{array}{l}\text { - Ensuring Effective General and Application } \\
\text { Controls } \\
\text { - Data Stewardship }\end{array}$ \\
\hline
\end{tabular}




\section{TABLE OF CONTENTS}

Preface i

Framework for Assessing the Acquisition Function iii

Executive Summary vii

Cornerstone 1: Organizational Alignment and Leadership 1

Cornerstone 2: Policies and Processes 11

Cornerstone 3: Human Capital 29

Cornerstone 4: Knowledge and Information Management 41

Appendix I: Scope and Methodology 51

Appendix II: Additional Sources of Information 53

This is a work of the U.S. government and is not subject to copyright protection in the United States. It may be reproduced and distributed in its entirety without further permission from GAO. However, because this work may contain copyrighted images or other material, permission from the copyright holder may be necessary if you wish to reproduce this material separately. 


\section{Executive Summary}

\begin{tabular}{|l|}
\hline What this framework is \\
\hline$\checkmark$ General guidance to evaluate \\
an agency's acquisition \\
function and to identify areas \\
that need improvement \\
$\checkmark$ Consistent with and integrates \\
existing guidance and \\
standards \\
\hline What this framework is not \\
\hline$\checkmark$ A tool to evaluate specific \\
acquisition actions, contracts, \\
compliance with contracting \\
laws and regulations, or a \\
source of detailed assessment \\
questions \\
$\checkmark$ A substitute or replacement for \\
existing standards \\
\hline
\end{tabular}

Federal agencies have responsibility for a vast array of missions - assuring national defense, building and maintaining the nation's infrastructure, assessing and collecting tax revenue, advancing scientific knowledge, and promoting the health and well-being of the nation's citizens, among many others. To achieve these various missions, federal agencies use a variety of approaches and tools, including contracts to acquire goods and services needed to fulfill or support the agencies' missions. Federal agencies award contracts worth over $\$ 300$ billion annually. Acquiring these goods and services in an efficient, effective, and accountable manner is therefore essential. However, our work - as well as the work conducted by the inspectors general, other accountability organizations, and the agencies themselves - continues to identify systemic

weaknesses in key areas, which often result in cost, schedule, and performance problems on individual procurements.

GAO has developed this framework to provide senior acquisition executives, as well as GAO and other accountability organizations, an ability to assess at a high level the strengths and weaknesses of agencies' acquisition functions. This framework comprises four interrelated cornerstones that our work has shown promote an efficient, effective, and accountable acquisition function: (1) organizational alignment and leadership, (2) policies and processes, (3) human capital, and (4) knowledge and information management. These four cornerstones are summarized below.

\section{CORNERSTONE 1: ORGANIZATIONAL ALIGNMENT AND LEADERSHIP}

Organizational alignment is the appropriate placement of the acquisition function in the agency, with stakeholders having clearly defined roles and responsibilities. There is no single, optimal way to organize an agency's acquisition function. Each agency must assess whether the current placement of its acquisition function is meeting its organizational needs. Committed leadership enables officials to make strategic decisions that achieve agencywide acquisition outcomes more effectively and efficiently. 
CORNERSTONE 2: POLICIES AND PROCESSES

Implementing strategic decisions to achieve desired agencywide outcomes requires clear and transparent policies and processes that are implemented consistently. Policies establish expectations about the management of the acquisition function. Processes are the means by which management functions will be performed and implemented in support of agency missions. Effective policies and processes govern the planning, award, administration, and oversight of acquisition efforts, with a focus on assuring that these efforts achieve intended results.

\section{CORNERSTONE 3: HUMAN CAPITAL}

The value of an organization and its ability to satisfy customers depends heavily on its people. Successfully acquiring goods and services and executing and monitoring contracts to help the agency meet its missions requires valuing and investing in the acquisition workforce. Agencies must think strategically about attracting, developing, and retaining talent, and creating a results-oriented culture within the acquisition workforce.

\section{CORNERSTONE 4: KNOWLEDGE AND INFORMATION MANAGEMENT}

Effective knowledge and information management provides credible, reliable, and timely data to make acquisition decisions. Each stakeholder in the acquisition process - program and acquisition personnel who decide which goods and services to buy; project managers who receive the goods and services from contractors; commodity managers who maintain supplier relationships; contract administrators who oversee compliance with the contracts; and the finance department, which pays for the goods and services-need meaningful data to perform their respective roles and responsibilities.

The framework is built on a foundation of strong internal control. Agency management is responsible for establishing and maintaining effective internal control, which includes the plans, methods, and procedures used to meet missions, goals, and objectives. Internal control serves as the first line of defense in safeguarding assets and preventing and detecting errors and fraud. The five standards of internal control—control environment, risk assessment, control activities, information, and communications-support the framework's four interrelated cornerstones. 


\section{Using the Framework}

The main sections in this guide focus on the four interrelated cornerstones. To assist the user in applying the framework, each cornerstone is broken down into elements and critical success factors. Each element is integral to effective stewardship at an organization and depends on critical success factors. The presence of critical success factors-which focus on program results and mission accomplishment-can enhance the likelihood of consistently achieving desired acquisition outcomes. Conversely, the absence of these critical success factors can point to areas embodying high degrees of risk or those needing greater management attention.

To help users discover whether their organizations are employing critical success factors, we offer three indicators: questions to ask, situations to look for, and caution signs to be aware of. These indicators can be found by looking for the following symbols throughout this framework-

\section{? KEY QUESTIONS}

What to ask when trying to identify the presence or absence of critical success factors.

\section{* LOOK FOR}

Indicators of practices and activities that facilitate good acquisition outcomes.

\section{A cautions}

Indicators of practices and activities that hinder good acquisition outcomes. 


\section{Organizational Alignment

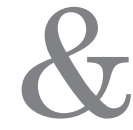 \\ Leadership}

\begin{tabular}{|l|l|}
\hline Elements & Gritical Success Factors \\
\hline $\begin{array}{l}\text { Aligning Acquisition with } \\
\text { Agency's Missions and } \\
\text { Needs }\end{array}$ & $\begin{array}{l}\text { - Assuring Appropriate Placement of the } \\
\text { Acquisition Function } \\
\text { - Organizing the Acquisition Function to Operate } \\
\text { Strategically } \\
\text { - Clearly Defining and Integrating Roles and } \\
\text { Responsibilities }\end{array}$ \\
\hline $\begin{array}{l}\text { Commitment from } \\
\text { Leadership }\end{array}$ & $\begin{array}{l}\text { - Clear, Strong, and Ethical Executive Leadership } \\
\text { Effective Communications and Continuous } \\
\text { Improvement }\end{array}$ \\
\hline
\end{tabular}

In This Chapter We focus on two elements and five critical success factors that can be used to assess the placement of an agency's acquisition function and the effectiveness of its leadership. 


\section{Organizational Alignment AND LEADERShiP}

Organizational alignment is the appropriate placement of the acquisition function in the organization, with stakeholders having clearly defined roles and responsibilities. For example, Congress requires certain civilian executive agencies to designate a chief acquisition officer to take primary responsibility for managing agency acquisitions. In establishing chief acquisition officers, Congress recognized that the person in charge of the agency's acquisition function must have a respected and well-defined role that is consistent with the role of acquisition in meeting the agency's missions. Executive leadership is key to obtaining and maintaining organizational support for executing the acquisition function. Executive leadership determines the relationship between the various functional departments and is key to strengthening the interaction between the agency's management and employees.

Although there is no single, optimal way to organize an agency's acquisition function, officials from leading companies tell us that effective organizational alignment enables them to implement a coordinated and strategically oriented approach to acquisition activities. Similarly, to move toward a more resultsoriented government, agencies must ask themselves how they can use acquisitions strategically to help them achieve their goals.

\section{Aligning Acquisition with Agency's Missions and Needs $\quad$ ELEmENT}

The end goal of organizational alignment is to ensure that the acquisition function enables the agency to meet its overall missions and needs. The acquisition function needs proper management support and visibility within the organization to meet that goal.

\section{Assuring Appropriate Placement of the Acquisition Function}

In response to market and other pressures, leading companies have assessed the current placement of their acquisition function to determine if it is meeting organizational needs, including acquiring needed goods and services, supporting strategic decision making, and ultimately improving overall business performance. In many cases, these organizations cut across traditional boundaries that contributed to a fragmented approach to buying goods and services by restructuring their acquisition function and typically assigning it growing responsibility and authority. Similarly, each agency must assess the current placement of its acquisition function to determine if it is meeting the agency's needs. 


\section{? KEY QUESTIONS}

- What percentage of the discretionary budget does the agency spend on the acquisition of goods and services?

- Where is the acquisition function currently placed in the agency?

- What are the roles and responsibilities of the acquisition function and acquisition personnel in the agency?

- Do agency leaders, management, and staff view the acquisition function as a strategic asset in achieving their missions or supporting the agency's operations at lowest possible cost?

- To what extent is the agency's acquisition spending managed or influenced by the agency's acquisition office?

\section{* LOOK FOR}

- The acquisition function has been assigned the appropriate degree of responsibility and authority for strategic planning, management, and oversight of the agency's purchases of goods and services, and this responsibility is consistent with the significance of acquisition to the agency's missions.

- Agency leaders view the acquisition function as a strategic asset in support of core agency missions and business processes.

- Agency managers and staff view the acquisition function as a business partner rather than a support function.

- Acquisition of goods and services is viewed from an agencywide perspective.

\section{A cautions}

- Disconnects exist between where the acquisition function is placed in the agency's hierarchy and its role in achieving the agency's missions or supporting its operations.

- Lack of coordination across the acquisition function results in redundancy, inconsistency, and an inability to leverage resources to meet common or shared requirements.

- Staff views the acquisition function merely as an administrative support function rather than as a business partner.

\section{Critical Success Factor Organizing the Acquisition Function to Operate Strategically}

How an agency organizes and manages its acquisition function affects its ability to operate strategically. Traditionally, the acquisition function has been fragmented among business units, as each was responsible for its own acquisition activities. We found that leading organizations transformed the acquisition function from one focused on supporting various business units to one that is strategically important to the bottom line of the whole company. 


\section{? KEY QUESTIONS}

- Has the agency assessed the current structure of the acquisition function and related controls? If so, what were the results of the study?

- Has the agency experienced significant changes in its missions, budget, workforce, technology, or other internal or external factors? What changes, if any, did the agency make in response to such factors?

- Does the agency have mechanisms to anticipate, identify, and react to risks presented by changes in conditions that can affect agencywide or acquisitionrelated goals?

- Does the agency have metrics related to acquisition efficiency, effectiveness, and results that are included as part of overall performance plan and communicated regularly to senior leaders and management? Are these metrics linked to agency missions and goals?

- Does the agency use its strategic and annual performance plan to document the contribution that agency officials expect the acquisition function will make to the agency's missions, strategic goals, and annual goals?

\section{* LOOK FOR}

- The acquisition function's mission is well-defined, and its vision for the future, core values, goals, and strategies are consistent with and support the agency's overall missions.

- The current structure of the acquisition function has been assessed in response to changes, such as in the missions, operating environment, budget, workforce, or technology.

- Outcome-oriented performance measures are used to assess the success of the acquisition function. These measures should be designed to gauge the contribution that the acquisition function makes to support the agency's missions and goals.

\section{$\triangle$ cautions}

- The agency lacks a clear definition of the acquisition function's mission, vision, core values, goals, or strategies.

- The agency has not assessed the role of the acquisition function in response to significant changes.

- The agency lacks a mechanism for addressing risks that arise in response to changing conditions.

- Performance measures are not used to evaluate the usefulness of the acquisition function to support the agency's missions. 


\section{Critical \\ Success FActor Clearly Defining and Integrating Roles and Responsibilities}

An acquisition function that is successful at effectively and efficiently meeting the agency's missions generally reflects a consistent, cross-functional, and multidisciplinary approach. This approach requires engagement by all relevant stakeholders, including representatives from program offices, contracting officials, financial managers, human capital officials, information technology officials, and other appropriate participants. An integrated approach helps agencies better define their needs and identify, select, and manage providers of goods and services.

\section{? KEY QUESTIONS}

- What are the roles and responsibilities of stakeholders in the agency's acquisition process?

- Does the agency empower stakeholders to coordinate, integrate, and ensure consistency among acquisition actions?

- How are stakeholders held accountable for their actions?

\section{* Look For}

- Each stakeholder in the acquisition process has clearly defined roles and responsibilities.

- There is a shared understanding of each participant's role in acquisition activities.

- Key stakeholders are empowered to coordinate, integrate, and implement decisions about acquisitions.

- Acquisition managers support the agency's strategic-planning and decisionmaking needs at field and headquarters levels.

\section{A cautions}

- The acquisition function's role is unclear.

- Acquisition and other agency offices do not clearly communicate and cooperate.

- There is little integration of acquisition planning among the different agency entities with a role in acquisitions.

- Conflicts among stakeholders are left unresolved, thereby resulting in inefficient operations.

- The agency's acquisition office is frequently bypassed. 
Organizations recognized for their best practices cite leadership as the most critical factor in providing direction and vision and, if necessary, changing the organization's culture. Leaders have the responsibility to set the corporate agenda, define and communicate the organization's values and culture, and remove barriers that block organizational changes. Research has found that lack of senior leadership commitment is the cause of most reengineering failures.

Congress recognized the critical role leaders play in providing direction and vision by requiring certain civilian agencies to designate a chief acquisition officer to take primary responsibility for managing acquisitions. The officer's responsibilities include evaluating the performance of acquisition programs, advising the agency head on business strategies, and directing acquisition policy for the agency, among others.

\section{Clear, Strong, and Ethical Executive Leadership}

\section{Critical}

Powerful, visionary leaders can set the direction, culture, and perceptions of the agency. Clear, strong, and ethical executive leadership can enable staff across the agency to work in an integrated fashion toward common goals.

\section{? KEY QUESTIONS}

- Does the agency have a chief acquisition officer? Is the officer's primary responsibility managing acquisitions?

- Has senior leadership articulated a strategic, integrated, and agencywide vision for the acquisition function?

- Is senior leadership actively involved in pursuing changes, if appropriate, to how the agency acquires goods and services?

- Are managers at all levels held accountable for their contributions to the acquisition process?

- Does agency leadership promote integration and coordination among the agency's budgetary processes and human capital, acquisition, and financial management functions?

- Does agency leadership and management have a positive and supportive attitude toward internal control?

- Has agency management recently reviewed its key acquisition-related internal controls? If so, what were the results? Are all aspects of the acquisition program covered in the internal control review? 
- Does agency management take a proactive stance to correct any deficiencies identified in its acquisition-related internal controls?

- Has the agency established policies, such as a code of conduct, communicating appropriate ethical standards? How does the agency ensure that it interacts with the contractor community in a fair, equitable, and ethical fashion?

\section{* LOOK FOR}

- The agency has a chief acquisition officer dedicated to managing acquisitions in the agency.

- Senior leadership provides direction and vision, facilitates the development of common processes and approaches, and is involved in identifying and assessing risks associated with meeting acquisition objectives.

- Senior leadership promotes a strategic, integrated, and agencywide approach to acquisition, as appropriate.

- Improvement initiatives involve stakeholders from across the agency.

- Senior leadership and management set a positive and supportive attitude toward internal control.

- Senior leadership and management support monitoring to assess the quality of internal control performance and to ensure that issues are promptly resolved.

- Senior leadership and management have assessed risks the agency faces from external and internal sources in relation to acquisition objectives.

- Actions taken to address risks are effectively implemented.

\section{A cautions}

- There is no chief acquisition officer, or the officer has other significant responsibilities and may not have management of acquisition as his or her primary responsibility.

- Senior leadership has not defined a common direction or vision for the acquisition function.

- Senior leadership does not continually support efforts to develop common processes and approaches.

- Senior leadership does not adequately set and maintain the agency's ethical tone, provides little guidance for proper behavior, and fails to remove temptations for unethical behavior or provide discipline when appropriate.

- Senior leadership has not comprehensively identified risks and considered all significant interactions between the agency and other parties.

- Agency management does not have adequate resources and support to implement common process and approaches.

- Agency personnel do not understand the importance of developing and implementing good internal controls. 


\section{Effective Communications and Continuous Improvement}

Agency leadership needs to effectively communicate to employees the agency's missions, values, and guiding principles. Leaders use meaningful metrics to measure the effectiveness of the acquisition function and to provide the foundation for continuous improvement. Leading organizations use performance measurements to gain insight into and make judgments about (1) an organization's current performance level, (2) the critical processes that require focused management attention, (3) realistic goals for improvement, and (4) results over time.

\section{? KEY QUESTIONS}

- How does agency leadership communicate the agency's missions, values, and guiding principles, as well as its vision and expectations for the acquisition function, to agency personnel?

- Have agency personnel been asked for their views on the effectiveness of this communication?

- Does agency leadership facilitate and support clear lines of communication among all parties?

- Have stakeholders been asked for their views on the effectiveness of the existing acquisition process and areas needing improvement?

- What metrics does the agency use to demonstrate the impact and value of the acquisition function in supporting the agency's missions?

- What process does the agency use to develop these metrics?

- Are control activities an integral part of the agency's planning, implementation, review, and accountability activities to ensure results and stewardship of government resources?

- Does the agency or an independent organization continuously monitor control activities for their effectiveness at ensuring acquisition objectives are met?

\section{* LOOK FOR}

- Agency leadership listens to its program units and other affected parties' needs and concerns and remains open to revising acquisition processes as appropriate.

- Revisions to processes reflect appropriate incorporation of affected parties' needs and concerns.

- Metrics used by agency leadership are targeted at demonstrating the impact and value of the acquisition function and provide useful feedback to identify areas for improvement. 


\section{A cautions}

- There is inadequate communication from agency leadership regarding the effectiveness of the acquisition function and how it supports agency missions.

- There is no mechanism in place for stakeholders to provide suggestions for improvement to the acquisition process.

- Little change is made to acquisition processes based on the needs and concerns expressed by affected parties.

- Internal control monitoring does not occur in the course of normal operations, is not performed continually, and is not ingrained in the agency's operations.

- The agency has inadequate policies, procedures, techniques, and mechanisms in place to ensure effective implementation of management directives.

- The agency has not implemented a program to continuously measure and assess the acquisition function's performance in supporting the agency's missions or achieving acquisition goals.

- Performance measures are in place but are not consistently utilized or communicated.

\section{QUICK RECAP: How Organizational Alignment and Leadership Can Enhance the Acquisition Function}

Where the acquisition function falls in the agency's hierarchy and how the function is perceived are in balance with the overall agency missions.

$\checkmark$ Agency leadership views the acquisition function as a strategic asset.

$\checkmark$ Staff views the acquisition function as a business partner rather than merely a support function.

$\checkmark$ An integrated approach to acquisition - involving stakeholders from program, contracting, finance, and human capital offices-helps agencies better define their needs and identify, select, and manage providers of goods and services.

$\checkmark$ Agency leadership enables an integrated and agencywide approach to acquisition.

$\checkmark$ Effective communications and use of measurements allow leaders to actively assess and continuously improve performance.

$\checkmark$ Agency leadership establishes and maintains an environment that fosters a positive and supportive attitude toward internal control and conscientious management.

Learn more about organizational alignment and leadership by reading the reports found in appendix II. 


\section{Policies}

\&

\section{Processes}

\begin{tabular}{|l|l|}
\hline Elements & Gritical Success Factors \\
\hline Planning Strategically & $\begin{array}{l}\text { - Partnering with Internal Organizations } \\
\text { - Assessing Internal Requirements and the Impact } \\
\text { of External Events }\end{array}$ \\
\hline $\begin{array}{l}\text { Effectively Managing the } \\
\text { Acquisition Process }\end{array}$ & $\begin{array}{l}\text { - Empowering Cross-Functional Teams } \\
\text { - Managing and Engaging Suppliers } \\
\text { - Monitoring and Providing Oversight to Achieve } \\
\text { Desired Outcomes } \\
\text { - Enabling Financial Accountability }\end{array}$ \\
\hline $\begin{array}{l}\text { Promoting Successful } \\
\text { Outcomes of Major Projects }\end{array}$ & $\begin{array}{l}\text { - Using Sound Capital Investment Strategies } \\
\text { - Employing Knowledge-Based Acquisition } \\
\text { Approaches }\end{array}$ \\
\hline
\end{tabular}




\section{Policies ANd Processes}

Policies and processes embody the basic principles that govern the way an agency performs the acquisition function. Ideally, policies and processes clearly define the roles and responsibilities of agency staff, empower people across the agency to work together effectively to procure desired goods and services, and establish expectations for stakeholders to strategically plan acquisitions and proactively manage the acquisition process. To be effective, policies and processes must be accompanied by controls and incentives to ensure they are translated into practice. Major acquisitions require special attention to promote successful outcomes. Policies and processes that fail to address these objectives contribute to missed opportunities to achieve savings, reduce administrative burdens, and improve acquisition outcomes.

Planning strategically requires attention to the larger context within which acquisitions occur. First, it requires identifying and managing relationships among the parties involved in the acquisition process. Second, sufficient attention should be given to analyzing aggregate agency needs and devising strategic acquisition plans to meet those needs. Acquisition planning should also take into consideration the effects of the appropriations process and other external factors on the timing and execution of major contracts.

\section{Partnering with Internal Organizations

Leading organizations have found that an acquisition function that successfully supports their missions generally employs a multidisciplinary approach. This approach requires engagement by all stakeholders, including contracting, finance, legal, and other appropriate participants to identify needs, assess alternatives, develop cost-effective acquisition approaches, and help ensure financial accountability.

\section{? KEY QUESTIONS}

- Do end-users of the goods and services acquired work with the acquisition office to discuss requirements for meeting end-users' needs?

- Do stakeholders work together to develop a joint strategy for acquisitions?

- How receptive are stakeholders to evaluating different acquisition approaches and solutions and making trade-off decisions?

- How does the agency promote coordination among the stakeholders as an acquisition action moves through the various steps in the process?

- Do stakeholders work together to understand each other's needs? 


\section{(2) LOK FOR}

- The agency has empowered stakeholders and holds them accountable for coordinating, integrating, and implementing effective acquisition decisions.

- Acquisition planning and strategy development support the agency's missions rather than focus on the needs of individual units.

- Stakeholders work on an ongoing basis to define key business and acquisition drivers and to understand each other's needs.

- Lessons learned are identified and shared among stakeholders.

- The agency has structures in place that require appropriate coordination among stakeholders developing and implementing acquisition strategies.

\section{$\triangle$ cautions}

- There are only limited mechanisms for coordinating acquisitions in the agency.

- Stakeholders do not clearly communicate their needs or work together to identify solutions.

- Lack of integration across the acquisition function results in redundancy, inconsistency, and an inability to leverage resources to meet shared requirements.

- Acquisition and financial management executives do not partner to develop a shared vision.

\section{Assessing Internal Requirements and the Impact of External Events}

Successful acquisition strategies require sufficient attention to analyzing agencywide needs. Acquisition planning should include market research to identify appropriate products and services, determination of the extent of competition in the market, assessment of core competencies and opportunities to compete commercial-type activities, and identification of contract approaches that best meet end-users' needs. Additionally, past acquisitions should be reviewed to identify trends and opportunities for consolidating similar acquisitions planned in the coming year to leverage buying power and reduce administrative burdens.

Acquisition planning should take into consideration the effects of the appropriations process on the timing and execution of major contracts. Additionally, agencies must be cognizant of congressional mandates, administration initiatives, socioeconomic policy objectives, governmentwide fiscal imbalances, and other factors external to agencies. Additionally, acquisition processes should be sufficiently flexible to address unforeseen external events and emergencies. 


\section{? KEY QUESTIONS}

- Does the agency strategically assess its needs and develop acquisition approaches to help it meet those needs?

- Does the agency leverage purchasing volume by identifying agencywide acquisitions of goods and services?

- Does the agency systematically identify and analyze agencywide acquisitions planned in the next 12 to 24 months?

- Are needs identified in the budget request submission consistent with planned acquisition strategies?

- Does the agency track the types of acquisition methods used for acquiring goods and services to ensure it is employing the most appropriate contract type?

- Does the agency have a mechanism to review planned acquisitions and identify opportunities for suppliers from the small or disadvantaged business community? Has the agency achieved its goals in each of the socioeconomic acquisition categories?

- Has the agency determined the type or extent of work that is and should be performed in-house and which could be contracted out?

- Has the agency assessed its core competencies and identified opportunities to compete commercial-type activities?

- Do agency officials track new or pending legislation that might affect acquisition policies and processes, training, and workload?

- Have agency officials assessed whether their acquisition processes are capable of responding to unforeseen external events and emergencies?

- Do agency officials carefully consider how to meet competing demands on the acquisition system?

\section{* LOOK FOR}

- Strategic acquisition plans are current and reflect anticipated budgetary resources.

- The agency considers recurring purchases and develops acquisition plans that best leverage these acquisitions.

- The agency appropriately selects among contracting tools available, including commercial item acquisition, performance-based contracting, and government purchase cards to best meet end-user needs in a cost-effective manner.

- Adequate and relevant data are available and used to make strategic decisions about what work the agency should perform in-house and to identify opportunities to compete work with the private sector.

- The agency identifies opportunities for small and disadvantaged businesses and consistently achieves socioeconomic goals.

- There is an awareness of current and pending legislation and its potential implications on the agency's acquisition policies, processes, and practices.

- The agency has assessed and incorporated changes, as appropriate, to enable its acquisition processes to better respond to unforeseen external events and emergencies.

- There is an awareness of the agency's long-term budgetary outlook. 


\section{A cautions}

- The agency lacks a strategic acquisition plan.

- Acquisition planning is completed on a contract-by-contract basis rather than with consideration of agencywide needs.

- The agency lacks data on the types of contracts used on procurement actions.

- Frequent emergency or sole-source purchases are made to meet routine or recurring agency needs.

- The agency fails to achieve socioeconomic goals.

- Little knowledge exists of what work is contracted out and what work is performed in-house.

- The agency has not assessed its core competencies or identified opportunities to compete commercial-type activities.

- The agency makes frequent changes to acquisition plans due to unforeseen expenses or budgetary shortfalls.

- The agency is ill-equipped to purchase goods and services needed to respond to emergency situations.

\section{ELEment Effectively Managing the Acquisition Process}

The role of the acquisition function does not end with the award of contracts. Acquisitions that help the agency meet its needs require continued involvement throughout contract implementation and close-out. In other words, agency processes need to ensure that contracted goods and services will be delivered according to the schedule, cost, quality, and quantity specified in the contract. Factors that can help an agency effectively manage its acquisition process include empowering cross-functional teams, managing and engaging external suppliers, providing effective monitoring and oversight, and implementing sound financial accountability measures.

\section{Critical Success Factor Empowering Cross-Functional Teams}

Leading organizations make extensive use of cross-functional teams to make sure they have the right mix of knowledge, technical expertise, and credibility. This approach helps organizations better define their needs and identify, select, and manage providers of goods and services, which in turn helps ensure that users' needs are met at the lowest total costs to the organization. Teams may vary in size but generally include representatives from the organization's purchasing unit, internal users of goods and services, and the budget or finance office. Teams are responsible for analyzing spending data, identifying and prioritizing potential opportunities for more detailed review, defining internal needs and requirements, and conducting market research. 


\section{? KEY QUESTIONS}

- To what extent does the agency use cross-functional teams in performing acquisition activities? Are staff from field offices involved at any level? How?

- Do team members feel empowered to make decisions and are they invested in the project's outcome?

- Do the teams use a project plan to manage and control project implementation?

- Does the project plan include performance measurement baselines for schedule and cost, major milestones, and target dates and risks associated with the project?

- Do individuals outside the project team regularly review the status of cost, schedule, and performance goals?

- Are incentives in place to encourage teams to meet project goals?

- How are teams held accountable for meeting cost, schedule, and performance goals?

- Is there good communication among all stakeholders?

\section{* LOOK FOR}

- The agency uses cross-functional teams to plan for and manage projects. These teams develop a project plan to implement projects effectively.

- The agency systematically monitors project performance and establishes controls and incentives for accountability.

- Open, honest, and clear communication is encouraged among all parties, including team members, program officials, and contractors.

\section{A cautions}

- The agency makes limited use of cross-functional teams.

- Project team members do not feel empowered to make decisions or invested in the project outcome.

- Teams fail to use key elements of good project management techniques, including monitoring project performance and establishing controls and incentives to meet project goals.

\section{Managing and Engaging Suppliers}

Leading organizations have found that more cooperative business relationships with suppliers have improved their ability to respond to changing business conditions. Such relationships have led to lower costs, higher quality, and shorter product design and delivery times. Among the strategies employed by leading organizations are to establish commodity managers to oversee key goods and services and to establish an effective feedback system between the agency and its suppliers. 
Agencies can develop effective supplier relationships within the context of the Federal Acquisition Regulation by

$\checkmark$ establishing effective supplier relationship management as a core business strategy,

$\checkmark$ employing rigorous supplier selection to create a strong supplier base,

$\checkmark$ establishing commodity managers to more effectively manage key goods and services, and

$\checkmark$ establishing and maintaining an effective communication and feedback system with suppliers.

\section{? KEY QUESTIONS}

- Does the agency have a process to identify key suppliers?

- Does the agency use a rigorous supplier selection process to create a strong supplier base?

- Has the agency established commodity managers for key goods and services?

- What is the role of the commodity manager?

- Has the agency embraced effective supplier relationships as a core business strategy?

- Does the agency train its acquisition workforce on how to manage supplier relationships?

- Has the agency established an effective communication and feedback system with its suppliers to continually assess and improve its own and its suppliers' performance?

- Does the agency foster an environment in which suppliers invest their intellectual capital — their ideas—into the venture?

\section{* LOOK FOR}

- The agency uses stringent supplier selection criteria while maintaining an appropriate level of competition among suppliers.

- The agency has established commodity managers for key goods and services.

- Commodity managers are actively involved in defining requirements with internal clients, negotiating with potential providers of goods and services, and assisting in resolving performance or other issues after the contract is awarded.

- The agency has established an effective communication and feedback system with its suppliers, such as designating an authoritative person as a single interface with key suppliers;

- using integrated teams to facilitate sharing of information;

- establishing an objective basis for providing feedback by setting performance measures and expectations in terms of quality, responsiveness, timeliness, and cost;

- providing periodic "report cards" and meeting formally with key suppliers to discuss issues; and

- using surveys, supplier meetings, and formal agency-supplier councils or supplier advisory councils to assess existing customer-supplier working arrangements, identify problem areas, and report back to suppliers. 


\section{A cautions}

- Knowledge of its key suppliers is not shared across the agency.

- The agency does not take full advantage of the suppliers' intellectual capital, such as design or product ideas.

- The agency makes limited or no use of commodity managers to manage the acquisition of key goods and services.

- Commodity managers lack expertise, knowledge, or adequate training in the goods and services being procured.

- The agency is dependent on one or two suppliers for key goods or services.

- The agency continues to select the same suppliers without periodically assessing whether the goods and services offered are competitive in terms of price, quality, and performance.

- The acquisition workforce lacks the skills, knowledge, and expertise to manage supplier relationships effectively.

\section{Monitoring and Providing Oversight to Achieve Desired Outcomes}

Over the past decade, the federal government has increasingly relied on contractors to help carry out its missions. Consequently, agencies require effective oversight processes and staff with the right skills and training to ensure contractors provide the needed goods and services. Earned value management is one method to monitor large projects' progress toward cost, schedule, and performance goals.

\section{? KEY QUESTIONS}

- Does the agency track the types of acquisition methods used for acquiring goods and services to assess workload and training requirements?

- What tools, processes, and controls does the agency use to ensure effective oversight of contractor performance?

- What tools, processes, and controls does the agency use to ensure effective oversight of employees making purchases?

- What incentives does the acquisition workforce have to effectively monitor contractor performance?

- Does the agency clearly define the roles and responsibilities for those who perform contract management and oversight?

- What actions has the agency taken to ensure that it has adequate staff with the right skills, knowledge, and training to implement policies and processes and to oversee contractors?

- Do agency personnel or external parties with appropriate knowledge, skills, and responsibilities monitor internal control over the acquisition process on a continuous basis?

- Does the agency effectively use and require its contractors to use earned value management as an investment planning and control tool? 


\section{* LOOK FOR}

- The agency has undertaken a workforce-planning effort to ensure that individuals who award, manage, and monitor contracts have clearly defined roles and responsibilities and have the appropriate workload, skills, and training to perform their jobs effectively.

- The agency employs contract monitoring plans or risk-based strategies, and tracks contractor performance.

- The agency regularly reviews contract oversight processes, identifies areas needing improvement, and establishes and implements corrective action plans.

- The agency monitors the effectiveness of policies and processes, completes a cost benefit analysis when considering alternative policies and processes, and follows up on findings identified in monitoring efforts.

- The agency's suppliers have established earned value management systems, and the agency verifies that it and its suppliers effectively implement earned value management processes and procedures on all applicable programs.

\section{A cautions}

- Personnel responsible for contract management have skills and knowledge gaps that inhibit their ability to properly oversee the types of contracts used by the agency.

- The agency does not monitor whether its contracts meet cost, schedule, performance, and quality requirements.

- A significant percentage of contracts fail to meet cost, schedule, performance, and quality requirements.

- The agency does not assign clear roles and responsibilities for overseeing contracts.

- There are material weaknesses and/or reportable conditions related to acquisitions in the agency's performance and accountability report.

- Earned value data are unavailable or unreliable, and earned value management principles are not properly implemented.

\section{Critical Success Factor Enabling Financial Accountability}

The need for organizations to deliver goods and services despite shrinking budgets requires agencies to spend their resources wisely. Throughout the acquisition process, financial information should be tracked and communicated in a way that enables effective evaluation and assessment of acquisition activities. When financial data are not useful, relevant, timely, or reliable, the acquisition function-as well as other functions across an organization-are at risk of inefficient or wasteful business practices. 


\section{? KEY QUESTIONS}

- Does the acquisition workforce have access to and use timely contractual financial information to monitor and oversee individual acquisitions?

- Is the agency's financial management system integrated with its contract management system?

- Does the financial management system report frequently enough to provide reasonable assurance of accountability in acquisitions?

- Are financial data resulting from new contracts, task orders, and contract modifications clear and recorded properly?

- Does the agency measure how often erroneous or improper payments are made? Is a risk assessment process in place to address improper payments?

\section{* LOOK FOR}

- The acquisition workforce has ready access to information on obligated and expended funds, with sufficient information to assure proper oversight and accounting at the contract level.

- Entries are made to the financial management system that update the contract management and property accountability systems.

- The agency reports frequently enough-monthly or quarterly-to ensure accountability in the acquisition function.

- Adjustments to contract accounting records are clearly reported and accurate; such adjustments represent a low percentage of financial transactions.

- Erroneous and improper payments and cost overruns are tracked and are not a significant problem.

- The agency takes appropriate corrective action when the contractor is not meeting expectations for cost, schedule, or performance.

\section{A cautions}

- Acquisition and financial management staff lacks access to critical information, including fiscal year; appropriation/Treasury fund symbol; organization code; cost center; object classification; estimated amount; project code; program code; transaction date; action code; subject-to-funds-availability indicator; asset identifier code; contractor code/name; trading partner; trading partner code; award date; and amounts increased and/or decreased.

- Acquisition and financial management staff independently update the same types of data into independent financial and contract management systems.

- Financial management systems fail to provide transaction details to support account balances or identify the method of acquisition, lack evidence that the contractor's final invoice has been submitted and paid, or fail to perform other transaction processing and routine accounting activities adequately.

- Inadequate transaction processing, particularly improper payments, occur frequently.

- Financial management systems fail to include the taxpayer identification number for contractor identification and income reporting and debt collection purposes. 
- The agency receives a qualified, disclaimed, or adverse audit opinion, which may indicate poor accountability.

- Auditors note weaknesses in the agency's acquisition or financial management function in the agency's audit report.

\section{Element Promoting Successful Outcomes of Major Projects}

The federal government spends billions of dollars each year on major physical capital investment projects and to research, develop, and produce large custom projects. Capital investments and custom projects are generally expensive, span multiple years, and are crucial to the agency's strategy. Capital investments therefore usually require more analysis, support, and review than projects that cost less, have shorter time frames, or have less agencywide impact. Particular attention must be given to these long-term, capital-intensive projects.

\section{Critical Success Factor Using Sound Capital Investment Strategies}

Capital investment includes expenditures for water, power, and natural resource projects; construction and rehabilitation of Postal Service facilities and veterans' hospitals; major equipment; facilities for space and science programs; the air traffic control system; and information technology for the entire federal government.

To ensure an effective capital investment strategy, leading organizations

$\checkmark$ integrate organizational goals into the capital decision-making process;

$\checkmark$ evaluate, select, and control capital assets using an investment approach; and

$\checkmark$ balance budgetary control and managerial flexibility when funding capital projects.

\section{Integrating organizational goals into the capital decision-making process}

Leading organizations begin capital decision-making by defining the organization's mission in comprehensive terms and results-oriented goals and objectives. This process enables managers to identify resources needed to satisfy program requirements based on program goals.

\section{? KEY QUESTIONS}

- Are the agency's capital investments linked to and driven by its missions and long-term strategic goals?

- Has the agency completed a comprehensive capital investment needs assessment?

- Does the agency thoroughly consider alternatives to capital investments? 
- Does the agency perform an annual needs assessment on large capital investment projects lasting more than 1 year?

- Does the agency have an asset inventory? If so, does it contain assessments of the condition of the assets?

- Does the agency ensure it has the necessary resources available before beginning investments in capital projects?

\section{* LOOK FOR}

- Capital and strategic plans are clearly linked.

- The agency has completed a comprehensive needs assessment that considers the overall missions and identifies the resources needed to fulfill immediate requirements and anticipated future needs.

- Gaps between current and needed capabilities have been identified.

- The agency tracks the use and performance of existing assets and facilities.

- The agency routinely evaluates alternatives, including noncapital options, and repair and renovation of existing assets, before choosing to purchase or construct a capital asset or facility.

- The agency annually assesses capital investment projects lasting more than 1 year to assess the continued viability, need, and size of the project.

- The agency has an asset inventory that includes condition assessments.

- The agency ensures it has adequate time, money, technology, and other resources in place before beginning major projects.

\section{A cautions}

- Capital investment decisions are made without strategic consideration of what assets the agency already has and what it needs or the resources needed to fulfill its long-term and short-term goals and objectives.

- There is little consideration of alternatives to satisfy agency needs.

\section{Evaluating and selecting capital assets using an investment approach}

An investment approach builds on an agency's assessment of where it should invest its resources for the greatest benefit over the long term. Projects that are expensive, span multiple years, and are crucial to the agency's strategy usually require more analysis, support, and review than projects that cost less, have shorter time frames, or have less agencywide impact.

\section{? KEY QUESTIONS}

- Does the agency develop a decision or investment package, such as a business case, to justify capital project requests?

- Does the agency have preestablished criteria and a relative ranking of investment proposals? 
- Does the agency develop a long-term capital plan that defines capital asset decisions?

\section{* LOOK FOR}

- The agency develops an investment package that includes common categories of information, such as links to organizational objectives; solutions to organizational needs; project resource estimates and schedules; and project costs, benefits, and risks.

- The agency requires appropriate levels of management review and approval, supported by proper financial, technical, and risk analyses.

- Processes for ranking and selecting projects are based on preestablished criteria, a relative ranking of investment proposals and trade-offs, and an understanding of potential project risks.

- A long-term capital plan guides implementation of organizational goals and objectives and helps decision makers establish priorities in the long run.

\section{$\triangle$ cautions}

- No framework exists to ensure appropriate levels of management review, analysis, and approval for capital investment projects before initiating projects.

- Projects are selected without using preestablished criteria and without consideration of project risks.

- Year-to-year changes are made in the absence of a long-term capital plan, without consideration of strategic decisions.

\section{Balancing budgetary control and managerial flexibility}

Leading organizations generally require that the total life cycle costs of a project be considered when making decisions to provide resources. In the federal environment, to mitigate the risks of unplanned changes in future budgets, agencies may budget for "useful segments" of capital projects. ${ }^{1}$

\section{$?$ KEY QUESTIONS}

- Does the agency budget for useful segments of capital projects?

- Do managers have the necessary information to plan for capital investment projects? For example, does the agency have systems to estimate the full cost of a project?

- Are alternatives to full up-front funding considered when they may be in the

\footnotetext{
${ }^{1}$ The Office of Management and Budget has defined a "useful segment" as a component that (1) provides information that allows the agency to plan the capital project, develop the design, and assess the benefits, costs, and risks before proceeding to full acquisition (or canceling the acquisition) or (2) results in a useful asset for which the benefits exceed the costs even if no further funding is appropriated.
} 
best economic interest of the government?

\section{* LOOK FOR}

- The agency budgets projects in useful segments.

- Information and data systems are in place to develop estimates of the full cost of a project or segment early in the life of the project.

- The agency considers innovative approaches to full up-front funding, such as outsourcing capital-intensive services and developing public/private partnerships, when these are in the best economic interest of the government.

\section{A cautions}

- Capital projects are not funded in useful segments, which leads to acquisitions that may not be fully analyzed or justified, cancellation of major projects, and loss of associated sunk costs.

- Agencies lack information to make strategic capital investment decisions.

\section{Employing Knowledge-Based Acquisition Approaches}

The federal government spends billions annually to research, develop, and produce large custom projects, such as weapon systems, air traffic control systems, information technology, and space projects. Undesirable acquisition outcomes often occur, however, because agency officials proceed further into development or production without obtaining sufficient knowledge that the product will be able to meet established cost, schedule, performance, and quality targets.

The risk of undesirable acquisition outcomes can be significantly reduced. All product development efforts, whether for an automobile, airplane, missile, or satellite, go through a process of building knowledge. Ultimately, this process brings together and integrates the technology, components, and subsystems needed for the product to work and be reliably manufactured. GAO has identified three discrete points in the development process at which obtaining certain levels of knowledge promote successful outcomes. The attainment of each successive knowledge point builds on the preceding one. These knowledge points-technology maturity, design stability, and production process maturity—are defined in the following manner.

Knowledge point 1: A match between resources and needs occurs when the customer's requirements and the available resources-which are knowledge, time, and funding - correspond. Achieving a high level of technology maturity at the start of development is an important indicator of whether this match has been made.

Knowledge point 2: Design stability occurs when a program determines that a product's design is stable - that is, it will meet customer requirements and cost and schedule targets. 
Knowledge point 3: Production process maturity occurs when it has been demonstrated that the product can be manufactured within cost, schedule, and quality targets and that the process is repeatable and sustainable.

\section{? KEY QUESTIONS}

- Is a knowledge-based approach used to develop new products?

- What techniques does the agency use to match end-users' requirements with the technology resources available and the program's ability to meet cost and schedule predictions?

- Does the agency have an established metric or benchmark, such as the percentage of engineering drawings complete or similar criteria, to demonstrate that the product's design is stable?

- Is there an established metric or benchmark, such as having 100 percent statistical control over key manufacturing processes, to demonstrate that the product can be reliably produced and with high quality?

- Do program managers quantify the extent to which development efforts fail to achieve established benchmarks and assess whether those shortcomings are critical and correctable during the next phase?

- Does the agency measure the extent to which new product development activities meet the baseline cost, schedule, or performance requirements of the activities?

- Does the agency use lessons learned from programs that did not meet their baseline requirements to improve the agency's acquisition processes?

\section{* LoOK FOR}

- The agency embodies a knowledge-based approach to acquisition that is reinforced in its policies, implemented in its processes, reflected in individual acquisition decisions, and demonstrated through knowledge-based deliverables.

- At knowledge point 1 or an equivalent milestone, the agency regularly matches requirements and technology resources before beginning product development.

- At knowledge point 2 or an equivalent milestone, agency policy requires the developer to demonstrate that the design is able to meet requirements. To do so, the agency uses an established benchmark, such as the release of at least 90 percent of its engineering drawings, as its criteria.

- At knowledge point 3 or an equivalent milestone, agency policy requires the developer to demonstrate that the production process is mature and uses an established benchmark, such as 100 percent statistical control of key manufacturing processes, as its criteria. 


\section{A cautions}

- The agency does not use a knowledge-based process for developing new products.

- The agency does not use the necessary controls, such as demonstrating knowledge-based deliverables, to gauge whether adequate knowledge has been attained before deciding to move a product to the next phase of development.

\section{QUICK RECAP: How Policies and Processes Can Enhance the Acquisition Function}

$\checkmark$ Effective partnering with internal organizations and awareness of external factors that could impact acquisitions are two keys to strategic acquisition planning.

$\checkmark$ Effectively managing the acquisition process leads to improved acquisition outcomes and involves

- empowered agencywide teams,

- a strategy for managing external suppliers,

- monitoring and oversight, and

- steps to ensure financial accountability throughout the acquisition process.

$\checkmark$ Major acquisition projects, including capital investment and large custom projects, require special attention to achieve desired outcomes.

\section{Learn more about policies and processes by reading the} reports found in appendix II. 


\section{Human Capital}

\section{In This Chapter}

We present four elements and eight critical success factors to help agencies assess their human capital function in relation to acquisition.

\begin{tabular}{|l|l|}
\hline Elements & Gritical Success Factors \\
\hline $\begin{array}{l}\text { Valuing and Investing in the } \\
\text { Acquisition Workforce }\end{array}$ & $\begin{array}{l}\text { • Commitment to Human Capital Management } \\
\text { - Role of the Human Capital Function }\end{array}$ \\
\hline $\begin{array}{l}\text { Strategic Human Capital } \\
\text { Planning }\end{array}$ & $\begin{array}{l}\text { • Integration and Alignment } \\
\text { - Data-Driven Human Capital Decisions }\end{array}$ \\
\hline $\begin{array}{l}\text { Acquiring, Developing, and } \\
\text { Retaining Talent }\end{array}$ & $\begin{array}{l}\text { - Targeted Investments in People } \\
\text { - Human Capital Approaches Tailored to Meet } \\
\text { Organizational Needs }\end{array}$ \\
\hline $\begin{array}{l}\text { Creating Results-Oriented } \\
\text { Organizational Cultures }\end{array}$ & $\begin{array}{l}\text { - Empowerment and Inclusiveness } \\
\text { - Unit and Individual Performance Linked to } \\
\text { Organizational Goals }\end{array}$ \\
\hline
\end{tabular}




\section{HUMAN CAPITAL}

People are assets whose value can be enhanced through investment. Leading organizations understand that the success of an organization and its ability to satisfy customers is dependent on the contributions of its people. Human capital policies and practices should support an organization's overall missions and performance goals.

Human capital permeates virtually every effort within an agency, including successfully acquiring goods and services and executing and monitoring contracts. Effective human capital management ensures that an agency has the right staff in the right numbers applying skills where needed to accomplish the mission effectively. Creating an acquisition workforce with the right skills and capabilities can be a challenge, given changes to acquisition processes, the introduction or expansion of alternative contracting approaches, and increased reliance on services provided by the private sector. In addition, agencies are facing a growing number of employees who are eligible for retirement, which could create an imbalance with regard to acquisition experience and skill sets.

\section{Valuing and Investing in the Acquisition Workforce}

Successful acquisition efforts depend on agency leadership and management valuing and investing in the acquisition workforce.

\section{Commitment to Human Capital Management}

In leading organizations, senior leadership is committed to developing better ways to invest in human capital and are personally committed to implementing change.

\section{? KEY QUESTIONS}

- How does the agency's leadership demonstrate commitment to the acquisition workforce?

- What is the role of acquisition officials in developing the agency's human capital strategic plans?

- Does the agency have performance expectations for senior leaders and managers to foster collaboration within and across organizational boundaries and demonstrate a commitment to lead and facilitate change?

- How are senior leaders and managers held accountable for effectively managing the acquisition workforce? 


\section{* LOOK FOR}

- Acquisition officials play a significant role in developing the agency's overall human capital strategy and ensure that it reflects the goals of the acquisition function.

- Acquisition officials develop, implement, and evaluate human capital approaches designed to meet customer needs and improve overall business performance.

- Acquisition officials secure the support of managers at all levels for human capital approaches.

- Acquisition officials are held accountable for managing the acquisition workforce effectively.

- Acquisition employees are provided with resources for continuous learning efforts, competency-based appraisal systems, and retention and reward programs.

\section{A cautions}

- Agency leadership views people as costs rather than as assets.

- Agency leadership makes decisions about the workforce without considering how the decisions affect mission accomplishment.

- Agency leadership and management are not held accountable for managing the acquisition workforce.

- Business decisions proceed without consideration of the human capital needs they entail or human capital approaches necessary for success.

\section{Critical Success Factor Role of the Human Capital Function}

The human capital function should incorporate a strategic approach for accomplishing the agency's missions and program goals. This requires the agency to elevate the role of human capital professionals from paperwork processors to trusted advisors and partners of senior leaders and acquisition managers. To accomplish this, agency leaders need to ensure that human capital professionals have the appropriate authority, competencies, and experience.

\section{? KeY QUESTIONS}

- What are the roles and responsibilities of human capital officials with respect to the acquisition workforce?

- How do acquisition managers collaborate with human capital personnel to make hiring and staffing decisions? 


\section{* LOOK FOR}

- Human capital professionals partner with the agency's leaders and managers, including acquisition officials, to develop strategic and workforce plans.

- Human capital professionals use streamlined personnel processes and other means to meet customer needs, including hiring and retaining an acquisition workforce with the right skills.

\section{A cautions}

- Leaders view human capital management as a support or overhead function.

- Human capital management is largely process-oriented and compliancefocused.

- Acquisition and human capital officials do not coordinate with each other.

\section{Strategic Human Capital Planning}

By focusing on recruiting, hiring, training, and professional development, strategic workforce planning outlines ways to help the agency fill gaps in knowledge, skills, and abilities.

\section{Integration and Alignment}

Leading organizations take human capital into account when developing ways to accomplish their missions, program goals, and results. These organizations assess the effectiveness of the integration and alignment effort by how well human capital approaches help to achieve organizational goals.

\section{? KEY QUESTIONS}

- Does the agency have a strategic human capital plan that incorporates the needs of the acquisition function? If not, does the acquisition function have its own plan?

- Does the agency's strategic human capital plan address the use of contractors that provide commercial-type services to the agency?

- Does the agency's succession planning and management of its acquisition workforce: receive active support from top leadership; link to strategic planning; identify people with critical skills; emphasize development assignments in addition to formal training; and address such human capital challenges as diversity, leadership capacity, and retention? 
- Does the agency ensure that teams developing plans for the acquisition workforce consist of all stakeholders, such as customers or end-users, contracting officers, representatives from budget and finance, legal counsel, and human capital personnel?

- How does the agency track the effectiveness of human capital strategies for its acquisition workforce?

\section{* LOOK FOR}

- Comprehensive strategic workforce planning efforts.

- A strategic workforce plan that reflects the needs of the acquisition function, including consideration of which functions to maintain in-house.

- Strategies for recruiting, retaining, and developing acquisition staff, including performance measures to evaluate the contribution these strategies make in supporting the agency's acquisition function and achieving its mission and goals.

- A knowledge and skills inventory is used to identify current and future weaknesses and needs in acquisition skills.

\section{$\Lambda$ cautions}

- The agency does not fully recognize the link between its human capital approaches and organizational performance objectives.

- The agency adopts human capital approaches without considering how well they support organizational and acquisition goals and strategies or how these approaches may be interrelated.

\section{Critical \\ Success Factor Data-Driven Human Capital Decisions}

A fact-based, performance-oriented approach to human capital management is crucial to maximizing the value of human capital and to managing risk. Leading organizations use data to determine key performance objectives and goals, enabling them to evaluate the effectiveness of their human capital approaches.

\section{? KEY QUESTIONS}

- Who is included in the acquisition workforce?

- How does the agency track data on the acquisition workforce?

- How does the agency determine the appropriate size of its acquisition workforce?

- Is the mix of entry-level, mid-level, and top-level executives appropriate given the agency's missions and role of the acquisition function?

- What training and professional certifications have current acquisition employees attained?

- How does the agency track the workload of the acquisition staff? 
- Does the agency have a skills inventory for the acquisition workforce? How is it used to make human capital decisions?

- How long does the recruitment process take?

- What has the attrition rate been for the acquisition workforce?

- Does the agency conduct exit interviews with departing acquisition workforce employees to determine why people are leaving? If so, how are lessons learned used?

- What is the acceptance rate of applicants offered positions?

- How are training and development programs and results evaluated, and how does the agency track, report, and use this information?

\section{* LOOK FOR}

- Data on the agency's acquisition workforce are reflected in strategic workforceplanning documents. This includes size and shape of the workforce; skills inventory; attrition rates; projected retirement rates and eligibility; deployment of temporary employee/contract workers; dispersion of performance appraisal ratings; average period to fill vacancies; data on the use of incentives; employee feedback surveys; and feedback from exit interviews, grievances, or acceptance rates of job candidates.

- Data are available on staff development, including the number of people receiving training; money spent on training; and measures to determine the real impact on the agency's goals and objectives (such as increased productivity, enhanced customer satisfaction, increased quality, and reduced costs and errors).

- The agency uses data to evaluate and continuously improve the effectiveness of training and development programs.

\section{A cautions}

- Agency officials lack critical information with which to create a profile of the workforce or to evaluate the effectiveness of human capital approaches.

- Performance measures and goals for the agency's human capital programs, especially as they link to programmatic outcomes, have yet to be identified.

- The agency has little knowledge of what work is contracted out and what work is performed in-house.

\section{Acquiring, Developing, and Retaining Talent}

Recent trends in hiring and retirements in the federal government will leave many agencies with workforce imbalances in terms of skills, knowledge, and experience. Without sufficient attention given to acquiring, developing, and retaining talent, federal agencies could lose a significant portion of their contracting knowledge base. 


\section{CRItical
Success Factor Targeted Investments in People}

Leading organizations realize that investing in and enhancing the value of their acquisition staff benefits both employers and employees alike. For example, investing in training for the acquisition workforce is critical to ensuring adequate oversight of the quality, cost, and timeliness of goods and services delivered by third parties.

Industry and government experts recognize that training is a critical tool in successfully introducing and implementing new ways of doing business as well as reacting to change. An agency's overall training strategy-including planning, developing, implementing, and continuous improvement of its programs-is an important factor in ensuring staff has the necessary skills, knowledge, and experience to meet agency missions. The success of investment in training can be measured with balanced indicators that are results-oriented and clientbased, encompass employee feedback, and incorporate multiple dimensions of performance.

\section{? KEY QUESTIONS}

- What process does the agency follow to determine the appropriate level of spending on training, recruiting, and retention efforts?

- Does the agency have individual training plans established for all employees?

- Do employees have opportunities for continuous learning-such as attending meetings, seminars, and summits - to hear about best practices or otherwise stay up-to-date on issues in their fields?

- What are the training requirements for new and current acquisition staff and related positions?

- How is staff trained regarding new practices in acquisition?

- Does the agency have a comprehensive training management system that can track the delivery of training? Does it identify and track the associated costs of specific training and development programs?

- Do managers consistently provide resources (funds, people, equipment, and time) to support training and development priorities for the acquisition staff?

- Does the agency actively work with colleges and universities to: (1) market the opportunities available for acquisition professionals and (2) include a federal acquisition course that will prepare students for careers in federal acquisition and help promote federal career possibilities?

- Are model career paths charted for acquisition staff? 
reaches the right people at the right time; and measured the effectiveness of training.

- The agency targets investments in human capital to help it attract, develop, retain, and deploy talented, high-performing staff to accomplish its mission. These investments include training and professional development, recruiting bonuses, retention allowances, and skill-based pay.

- Goals, expectations, and criteria for investments in human capital development are clearly defined, transparent, consistently applied, and based on expected improvement in results.

- Agency investments are monitored and evaluated for effectiveness.

\section{$\bigwedge$ cautions}

- Training and other human capital expenditures are minimized rather than viewed as an investment.

- Funding decisions are made without clearly defined objectives or adequate consideration of how they will impact the workforce.

- The agency does not establish priorities, provide adequate funding, or track investments in human capital.

\section{Human Capital Approaches Tailored to Meet Organizational Needs}

Existing laws, rules, and regulations provide the agency with flexibility to offer competitive incentives to attract skilled acquisition employees; to create performance incentives and training programs; and to build constructive labormanagement relationships based on common goals. Such flexibility should enable agency officials to tailor their human capital approaches to their agency's specific needs and context.

When making decisions about the most appropriate approaches, the agency's acquisition officials should work with human capital professionals, managers, employees, and employee unions. Managers must be held accountable for applying these approaches in a fair and equitable manner across the agency.

\section{? KEY QUESTIONS}

- What human capital flexibilities have agency officials used over the past few years and with what results?

- What laws, regulations, or policies, if any, do agency officials view as limiting flexibility in human capital approaches? 


\section{* LOK FOR}

- The agency has a human capital strategy for the acquisition workforce, and it is based on the agency's missions.

- The agency explores opportunities to increase its competitiveness as an employer and eliminate barriers to building an effective, skilled acquisition workforce and takes appropriate action.

\section{A cautions}

- Managers view improvements in the acquisition workforce as improbable.

- Managers fail to fully explore the range of tools and flexibilities available under existing laws and regulations.

\section{element Creating Results-Oriented Organizational Cultures}

Leading organizations foster a work environment in which people are empowered and motivated to contribute to continuous learning and mission accomplishment.

\section{Critical
Success Factor}

Getting employees directly involved in the planning process helps to develop goals and objectives from a front-line perspective. Leading organizations commonly seek employee input on a periodic basis and explicitly address and use it to adjust their human capital approaches.

\section{? KEY QUESTIONS}

- Does the agency seek ideas from the acquisition workforce? Do employees feel a sense of ownership about policies and procedures?

- Do managers involve employees when planning and sharing acquisition performance information?

- Has the agency established a communication strategy to create shared expectations about the acquisition function and to report progress?

\section{* LOOK FOR}

- The agency obtains employees' ideas, involves employees in planning and sharing acquisition performance information, and incorporates employee feedback into new policies and procedures.

- Employee unions or councils are involved in major workplace changes, such as competitive sourcing or redesigning work processes.

- The agency has established a communication strategy to create shared 
expectations and report progress.

- Alternative dispute resolution programs are used effectively to resolve workplace disputes.

\section{A cautions}

- Managers and staff rigidly adhere to standardized procedures.

- Relations between management and employees and their representatives appear adversarial.

- Substantial time and resources are consumed by reacting to workplace disputes and long-standing sources of conflict.

\section{Unit and Individual Performance Linked to Organizational Goals}

Leading organizations find that effective performance management systems can transform their cultures to be more results-oriented, customer-focused, and collaborative in nature. These systems are used to achieve results, accelerate change, and facilitate discussions about individual and organizational performance throughout the year. An effective performance management system links organizational goals to individual performance for all acquisition-related employees and creates a "line of sight" between individual activities and organizational results.

\section{? KEY QUESTIONS}

- Has the agency recently assessed whether its performance management systems for the acquisition workforce adequately meet its needs?

- What efforts, if any, are underway to review or improve existing performance management systems?

- Does the agency's performance management system provide

- candid and constructive feedback to help individuals understand their contributions and help the organization achieve its goals;

- objective information to reward top performers; and

- documentation and information to deal with poor performers?

\section{* Look FOR}

- Individual performance expectations are aligned with organizational and crosscutting goals.

- Performance information is routinely used to track and plan follow-up actions to address organizational priorities.

- Competencies are used that enable fuller assessments of performance. 
- Pay is linked to individual and organizational performance.

- Meaningful distinctions in performance are made.

- Roles and responsibilities are defined and enable staff to maintain a consistent focus on programmatic priorities even during organizational transitions.

\section{A cautions}

- The agency has not aligned performance expectations with organizational goals.

- The agency does not use performance information to track progress at meeting organizational priorities.

\section{QUICK RECAP: How Human Capital Can Enhance the} Acquisition Function

$\checkmark$ Agency leadership and managers value and invest in the acquisition workforce.

$\checkmark$ Human capital professionals partner with acquisition managers to make staff development decisions.

$\checkmark$ Acquisition managers take human capital approaches into account when developing ways to attain organizational goals.

$\checkmark$ A strategic workforce plan profiles the current staff and projects staffing needs for the future.

$\checkmark$ The agency invests in talented, high-performing staff.

$\checkmark$ The agency fosters a work environment in which people are empowered and motivated to meet missions and goals.

Learn more about human capital by reading the reports found in appendix II. 


\section{Knowledge \& Information Management}

In This Chapter

We describe two elements and five critical success factors that focus on data essential to making good acquisition decisions.

\begin{tabular}{|l|l|}
\hline Elements & Gritical Success Factors \\
\hline $\begin{array}{l}\text { Identifying Data and } \\
\text { Technology that Support } \\
\begin{array}{l}\text { Acquisition Management } \\
\text { Decisions }\end{array}\end{array}$ & $\begin{array}{l}\text { - Tracking Acquisition Data } \\
\text { - Translating Financial Data into Meaningful Formats }\end{array}$ \\
\hline $\begin{array}{l}\text { Safeguarding the Integrity } \\
\text { of Operations and Data }\end{array}$ & $\begin{array}{l}\text { - Ensuring Effective General and Application } \\
\text { Controls } \\
\text { - Data Stewardship }\end{array}$ \\
\hline
\end{tabular}




\section{Knowledge And Information Management}

Knowledge and information management refers to a variety of technologies and tools that help managers and staff make well-informed acquisition decisions. Such decisions have a direct impact on many levels—program and acquisition personnel who decide which goods and services to buy; project managers who receive the goods and services from contractors; commodity managers who maintain supplier relationships; contract administrators who oversee compliance with the contracts; and the finance department, which pays for the goods and services. They all need meaningful data to perform their respective roles and responsibilities.

\section{Identifying Data and Technology that Support Acquisition Management Decisions}

Leading organizations gather and analyze data to identify opportunities to reduce costs, improve service levels, measure compliance with supplier agreements, and provide better management of service providers. Information systems help managers learn how much is being spent with which service provider and for what supplies or services. Additionally, data collected in support of meaningful metrics can assist agencies track achievements in comparison with plans, goals, and objectives. They can also allow agencies to analyze differences between actual performance and planned results. Generating meaningful data, however, requires good data stewardship.

When buying goods and services, many leading organizations have implemented comprehensive systems that integrate contracting, financial, and other data to support management decision making and external reporting requirements. These data

$\checkmark$ track events throughout the life of a contract;

$\checkmark$ monitor contractor performance and work progress;

$\checkmark$ record and validate the receipt of goods and services; and

$\checkmark$ link to human capital systems to obtain information that monitors workload levels of contracting officers and contract specialists, and workforce training and education.

The agency's financial systems support the preparation of auditable financial statements, track financial events, and help to ensure correct and timely payments for goods and services acquired. Financial data can, in conjunction with contracting and other data, enable strategic decision making by supporting an analysis of the 
agency's buying patterns. External data are obtained from commercial sources or other federal organizations. Examples include market research information and supplier financial status and performance.

Additionally, metrics, when designed to measure outcomes rather than inputs, can be used to: evaluate and understand an organization's current performance level; identify critical processes that require focused management attention; obtain the knowledge needed to set realistic goals for improvement; and document results over time.

\section{? KEY QUESTIONS}

- What acquisition-related data does the agency collect? Are data kept current?

- Are the agency's financial (including budgetary), acquisition, operating, and management information systems integrated? Do the systems provide timely, accurate, and relevant information?

- Do stakeholders believe the agency's information systems meet their business needs?

- How does the agency make needed data available to stakeholders within the acquisition process, such as program officials, commodity managers, and contracting officers?

- How does the agency manage institutional knowledge and identify and share best practices?

- Has the agency established specific goals and metrics-and collected data in support of those metrics-to assess the performance of the acquisition function?

\section{* LOOK FOR}

- Stakeholders generally agree that the agency's information systems provide credible, reliable, and timely information that they can use to make informed decisions.

- An effective agencywide system integrates financial, acquisition, operating, and management information and allows decision makers to access relevant information easily and perform ad-hoc data analysis.

- The agency's contracting management information system tracks events throughout the life of a contract, such as

- contract award;

- period of performance;

- contract modifications;

- key milestones;

- contractor performance, including cost and schedule status;

- contract closeout;

- identification of outstanding acquisition requests;

- expected cost; 
- types of goods and services acquired;

- receipt and acceptance of goods and services; and

- trouble spots and progress in dealing with them.

- Financial data - such as budgetary resources and funds availability, status of obligations and expenditures on individual contracts, outstanding purchase requests, and payments for the receipts of goods and services-are readily available to stakeholders.

- Knowledge and information management systems support strategic planning and performance improvement by enabling

- real-time benchmarking;

- sourcing and volume discount tracking;

- complete vendor information;

- contractors' past performance; and

- "what-if" analysis and planning.

- Data are available on the agency's overall "health," internal capabilities, and the external environment. Useful sources include

- agency financial statements;

- customer and employee satisfaction surveys;

- knowledge and skills inventories;

- workforce training and education data;

retention and recruitment reports; and

internal audit reports.

- Metrics have been established and are used to assess the effectiveness of the acquisition function, and measurements taken are credible.

- Metrics established allow the agency to assess the acquisition function's progress in meeting financial, customer satisfaction, and business operation objectives, as well as day-to-day activies, such as compliance with applicable laws, regulations, and best practices.

\section{$\bigwedge$ cautions}

- The agency has not collected the full set of information or data to make effective and fact-based decisions.

- Incomplete data prevent the agency from maximizing information tools for strategic acquisition planning and analysis.

- Data are not current, reliable, complete, or accurate.

- The agency does not make needed data accessible to decision makers, leading them to rely on informal, ad-hoc systems to make acquisition decisions.

- Decisions are not supported by demonstrable, underlying information.

- Lack of integration among systems hinders a user's ability to access acquisitionrelated information in a timely manner.

- Metrics established measure only inputs rather than outputs.

- Measurements taken in support of metrics are not credible, leading to disagreements over numbers and the value of the assessment process. 


\section{Critical
Success Factor Translating Financial Data into Meaningful Formats}

New technology tools can generate volumes of data, but the data are meaningless unless they can be translated into relevant, understandable formats for acquisition officials. Financial information is meaningful for acquisition officials when it is relevant, timely, and reliable, and enables them to manage costs, measure performance, and make program funding decisions.

\section{? KeY QUESTIONS}

- Do finance executives work with acquisition executives and managers to determine their information needs?

- What types of financial data or reports are regularly provided to acquisition officials?

- To what extent do acquisition personnel use financial information to support acquisition decisions?

\section{* Look For}

- Finance executives work with acquisition executives and managers on an ongoing basis to determine business and acquisition information needed to manage and oversee the agency's missions and objectives.

- Relevant financial information pertaining to acquisition is presented with suitable detail in an understandable format. Multiple levels of detail are available to provide complete and consistent obligation and expenditure information for an agency's overall contracting activities and for individual contracts.

- Financial management staff and officials receive feedback from acquisition staff and officials to ensure the acquisition function's data and reporting needs are being met.

\section{$\Lambda$ cautions}

- Financial information pertaining to acquisition is not of the proper scope, level of detail, timing, content, and presentation format to provide real value to users.

- Acquisition information received by financial management staff is not clear and understandable, impairing efficient processing of the information into management reports. 
Leading organizations continually analyze their spending on goods and services to answer basic questions about how much is being spent and where dollars are going. This approach is called "spend analysis." When organizations complete these analyses, they often realize they are buying similar goods and services from numerous providers, often at greatly varying prices.

\section{? KEY QUESTIONS}

- Does the agency regularly conduct and make use of spend analyses for key goods and services?

- What process does the agency use to conduct a spend analysis?

- Does the agency include purchases made with purchase cards in its spend analysis?

- If spend analyses have been conducted, how were the results used?

- Does the agency use a standard taxonomy to uniquely identify the products and services being analyzed?

\section{* LOOK FOR}

- The agency makes regular use of spend analysis techniques to support strategic planning efforts.

- The agency knows how much it is spending using purchase cards and has considered this information in its spend analysis.

- The agency uses a variety of information, including financial data, to conduct a spend analysis. At a minimum, the agency's spend analysis identifies

- what types of goods and services are being acquired;

- how many suppliers for a specific good or service the agency is using;

- how much they are spending for that good or service, in total and with each supplier;

- which units within the agency are purchasing the goods and services; and

- what goods and services have been or could be purchased to meet socioeconomic supplier goals.

\section{$\bigwedge$ cautions}

- The agency does not conduct or make regular use of spend analysis.

- The agency information and financial management systems are unable to provide credible, reliable, and timely data needed to conduct a spend analysis.

- Information is not maintained in a standardized format or is of poor quality, thus hampering efforts to use the data to more effectively manage goods and services spending. 
Internal controls-such as structures, policies, and procedures-promote efficiency, reduce the risk of asset loss, help ensure that financial and acquisition management systems issue reliable reports and that the organization is in compliance with laws and regulations. It is essential that acquisition management systems contain appropriate, cost-effective controls to safeguard assets, ensure accurate aggregation and reporting of information, and support the accomplishment of organizational objectives. Internal control actions and activities occur throughout an agency's operations and on an ongoing basis. Management must balance safeguards with the need to make accessible, timely, and accurate data available to managers and others needing acquisition information.

There are two broad groupings of information systems controls that can help safeguard the integrity of operations and data: general controls and application controls. Assessing general and application controls is a technical analysis and requires the assistance of persons knowledgeable in computer systems evaluation.

\section{Critical Success Factor Ensuring Effective General and Application Controls}

General control applies to all information systems and includes agencywide security program planning, management control over data center operations, system software, acquisition and maintenance, access security, and application system development and maintenance. Application control is designed to help ensure the completeness, accuracy, authorization, and validity of all transactions during application processing.

General and application controls over computer systems are interrelated. General control supports the functioning of application control, and both are needed to ensure complete and accurate information processing.

\section{? KEY QUESTIONS}

- When was the last information systems control review performed?

- What documentation exists of the reviews?

- What issues or problems did the reviews identify?

- How were the issues and problems addressed?

- What are the unresolved issues or problems?

- What is the impact of the unresolved issues and problems?

- What practices and procedures does the agency use to ensure that hardware and software are reliable, secure, and user-friendly? 


\section{LOOK FOR}

- Evidence in general controls that the structure, policies, and procedureswhich apply to all or a large segment of the agency's information systems-help to ensure proper operation, data integrity, and security.

- Evidence in application controls that the structure, policies, and procedures that apply to individual application systems - such as inventory or payrollproduce outputs that are complete, accurate, authorized, consistent, timely, relevant, and useful for its intended purpose.

\section{A cautions}

- The agency has not recently reviewed the internal controls governing its major systems.

- The agency has not addressed all identified major internal control issues or established corrective action plans.

\section{Data Stewardship}

Data stewardship ensures that data captured and reported are accurate, accessible, timely, and usable for acquisition decision making and activity monitoring. Effective stewardship provides the structure, oversight, and assurance that data can be accurately translated into meaningful information about organizational activities. Taking the time to manage quality of data ultimately helps support the agency's acquisition management needs.

\section{? KEY QUESTION}

- How does the agency ensure that data reflected in its knowledge and information management systems have the following properties:

- integrity of data;

- synchronization of data collection;

- reduced data redundancy;

- accessibility of data;

- transferability of data; and

- flexibility in the data management process?

\section{* LOOK FOR}

- The agency's internal controls provide reasonable assurance that data are accurate, complete, timely, and reliable.

- There is consistency among data definitions, sources, controls, and edit routines.

- Managers group data into logical categories and collect data according to commonly accepted reporting time frames. 
- Data are redundant only when necessary. Inconsistencies are eliminated.

- Data are accessible to authorized users when needed.

- Data can be transferred to other systems for operational, analytical, and forecasting processes.

\section{A cautions}

- Data are unreliable, incomplete, or unsuitable for efficient and effective management decisions.

- Users have little or no confidence in the credibility of the data and outputs from information systems.

- Management does not periodically test the reliability of its data.

QUICK RECAP: How Knowledge and Information Management Can Enhance the Acquisition Function

Acquisition personnel should track data on the contracting, financial, and external environment when developing an integrated acquisition information system.

$\checkmark$ Data are relevant, timely, reliable, and presented with suitable detail in understandable formats.

$\checkmark$ Spend analyses answer basic questions about how much is being spent and where the money is going.

$\checkmark$ Hardware and software are safeguarded to ensure the integrity of operations and acquisition data.

Learn more about knowledge and information management by reading the reports found in appendix II. 


\section{Appendix I: Scope And Methodology}

The purpose of this framework is to provide a systematic method for evaluating the acquisition function within federal agencies. The framework can be used to identify opportunities for improvements in acquisition processes as well as to highlight specific risks faced by each agency.

To develop the evaluation framework, we made use of the experience, knowledge, and expertise within GAO, the executive branch, state agencies, the private sector, and academia to develop key cornerstones that comprise an integrated acquisition function. The outline of the evaluation framework was then further refined in discussions with

- federal officials from a procurement executive council working group set up to assist GAO in assessing the acquisition function;

- individuals with acquisition expertise from the private sector and academia; and

- $\quad$ senior acquisition executives at a forum held at GAO in March 2004.

To provide us with a broad understanding of the weaknesses, issues, and potential reforms of the acquisition function, we consulted studies and reports from organizations such as Rand Corporation, the National Academy of Public Administration, the Australian National Audit Office, the National Association of State Purchasing Officials, the PricewaterhouseCoopers Endowment for the Business of Government, the Corporate Executive Board's Procurement Strategy Council, the Center for Advanced Purchasing Studies, and audit reports from GAO and various federal agency inspector general offices.

We also consulted guides on acquisition, human capital, financial management, and information technology from the Department of Defense, Office of Management and Budget, Office of Personnel Management, Department of Veterans Affairs, Department of Energy, Department of Transportation, Department of Treasury, Joint Financial Management Improvement Program, and GAO. Many of these resources are listed in appendix II.

To verify the accuracy of the information provided and improve the technical usefulness of the information reported, we asked acquisition, human capital, financial management, and information technology experts to review a draft of the evaluation framework. We incorporated their comments to create an exposure draft, which was distributed to obtain comments from interested parties of the federal, state and local acquisition community, acquisition experts from associations, academia, and professional organizations. We then incorporated these additional comments as appropriate in this publication. 


\section{Appendix II: AdDitional SourCes OF INFORMATion}

To download GAO reports, please visit our Web site at www.gao.gov and enter the report numbers specified below.

\section{Cross-Cutting InFormation}

U.S. Department of Energy, Office of Contract Management, Office of Procurement \& Assistance Management. Acquisition \& Financial Assistance Self-Assessment Checklist. Revised March 2005.

GAO. 21st Century Challenges: Reexamining the Base of the Federal Government. GAO-05-325SP. Washington, D.C.: February 2005.

GAO. Financial Management: Effective Internal Control Is Key to Accountability. GAO-05-321T. Washington, D.C.: February 16, 2005.

GAO. High-Risk Series: An Update. GAO-05-207. Washington, D.C.: January 2005.

U.S. Department of Energy, Office of Procurement and Assistance Management. Balanced Scorecard: Performance Measurement and Performance Management Program. Revised January 2005.

U.S. Department of Transportation. Department of Transportation's Procurement Performance Management System, Guidance Manual. Revision 3, October 2004.

GAO. Highlights of a GAO Forum: Workforce Challenges and Opportunities for the 21st Century: Changing Labor Force Dynamics and the Role of Government Policies. GAO-04-845SP. Washington, D.C.: June 2004.

GAO. Transportation Security Administration: High-Level Attention Needed to Strengthen Acquisition Function. GAO-04-544. Washington, D.C.: May 28, 2004.

GAO. Highlights of a GAO Forum on High-Performing Organizations: Metrics, Means, and Mechanisms for Achieving High Performance in the 21st Century Public Management Environment. GAO-04-343SP. Washington, D.C.: February 13, 2004.

Rand Corporation. Project AIR FORCE Research Brief: Speeding Acquisition Reform in the U.S. Air Force. RB-119-AF. Full report: MR-1711-AF. 2004.

U.S. Department of Energy. Office of Procurement and Assistance Management, Balanced Scorecard Performance Measures Information Document. Revised April 22, 2005.

Department of Veterans Affairs. Procurement Reform Task Force Report. May 2002. 
GAO. Best Practices: Taking a Strategic Approach Could Improve DOD's Acquisition of Services. GAO-02-230. Washington, D.C.: January 18, 2002.

GAO. Internal Control Management and Evaluation Tool. GAO-01-1008G. Washington, D.C.: August 2001.

Australian National Audit Office, Commonwealth of Australia. Contract Management: Better Practice Guide. February 21, 2001.

Schooner, Steven L. Fear of Oversight: The Fundamental Failure of Business-like Government. Washington, D.C.: American University Law Review, Vol. 50, No. 3, 2001.

GAO. Standards for Internal Control in the Federal Government.

GAO/AIMD-00-21.3.1. Washington, D.C.: November 1999.

Procurement Executives' Association. Guide to a Balanced Scorecard Performance Management Methodology. Chartered 1998.

Organizational AlignMent AND LEAdership

GAO. Military Transformation: Clear Leadership, Accountability, and Management Tools Are Needed to Enhance DOD's Efforts to Transform Military Capabilities. GAO-05-70. Washington, D.C.: December 17, 2004.

GAO. HUD Management: Actions Needed to Improve Acquisition Management. GAO-03-157. Washington, D.C.: November 15, 2002.

GAO. Business Process Reengineering Assessment Guide. GAO/AIMD-10.1.15. Washington, D.C.: May 1997, Version 3.

GAO. Reengineering Organizations: Results of a GAO Symposium. GAO/NSIAD-95-34. Washington, D.C.: December 13, 1994.

\section{Policies And Processes}

GAO. Defense Acquisitions: Assessments of Selected Major Weapon Programs. GAO-05-301. Washington, D.C.: March 31, 2005.

GAO. Best Practices: Using Spend Analysis to Help Agencies Take a More Strategic Approach to Procurement. GAO-04-870. Washington, D.C.: September 16, 2004.

GAO. Contract Management: Guidance Needed to Promote Competition for Defense Task Orders. GAO-04-874. Washington, D.C.: July 30, 2004. 
GAO. Information Technology: DOD's Acquisition Policies and Guidance Need to Incorporate Additional Best Practices and Controls. GAO-04-722. Washington, D.C.: July 30, 2004.

GAO. The Federal Acquisition Streamlining Act of 1994--Fair opportunity procedures under multiple award task order contracts. B-302499. Washington, D.C.: July 21, 2004.

GAO. Acquisition/Financial Systems Interface Requirements: Checklist for Reviewing Systems under the Federal Financial Management Improvement Act. GAO-04-650G. Washington, D.C.: June 2004.

GAO. Contract Management: Impact of Strategy to Mitigate Effects of Contract Bundling on Small Business Is Uncertain. GAO-04-454. Washington, D.C.: May 27, 2004.

GAO. Federal Acquisition: Increased Attention to Vehicle Fleets Could Result in Savings. GAO-04-664. Washington, D.C.: May 25, 2004.

GAO. Contract Management: Agencies Can Achieve Significant Savings on Purchase Card Buys. GAO-04-430. Washington, D.C.: March 12, 2004.

GAO. Defense Acquisitions: Stronger Management Practices Are Needed to Improve DOD's Software-Intensive Weapon Acquisitions. GAO-04-393. Washington, D.C.: March 1, 2004.

GAO. Financial Management: Some DOD Contractors Abuse the Federal Tax System with Little Consequence. GAO-04-95. Washington, D.C.: February 12, 2004.

GAO. Best Practices: Using a Knowledge-Based Approach to Improve Weapon Acquisition. GAO-04-386SP. Washington, D.C.: January 2004.

GAO. Contracting for Information Technology Services. GAO-03-384R. Washington, D.C.: February 14, 2003.

GAO. HUD Management: Actions Needed to Improve Acquisition Management. GAO-03-157. Washington, D.C.: November 15, 2002.

GAO. Contract Management: Guidance Needed for Using Performance-Based Service Contracting. GAO-02-1049. Washington, D.C.: September 23, 2002.

GAO. DOE Contractor Management: Opportunities to Promote Initiatives That Could Reduce Support-Related Costs. GAO-02-1000. Washington, D.C.: September 20, 2002.

GAO. Contract Reform: DOE Has Made Progress, but Actions Needed to Ensure Initiatives Have Improved Results. GAO-02-798. Washington, D.C.: September 13, 2002. 
GAO. Best Practices: Capturing Design and Manufacturing Knowledge Early Improves Acquisition Outcomes. GAO-02-701. Washington, D.C.: July 15, 2002.

Gansler, Jacques S. A Vision of the Government as a World-Class Buyer: Major Procurement Issues for the Coming Decade. The PricewaterhouseCoopers Endowment for the Business of Government. January 2002.

GAO. Information Technology: Leading Commercial Practices for Outsourcing of Services. GAO-02-214. Washington, D.C.: November 30, 2001.

GAO. Strategies to Manage Improper Payments: Learning from Public and Private Sector Organizations. GAO-02-69G. Washington, D.C.: October 2001.

GAO. Best Practices: DOD Teaming Practices Not Achieving Potential Results. GAO-01-510. Washington, D.C.: April 10, 2001.

GAO. Best Practices: Better Matching of Needs and Resources Will Lead to Better Weapon System Outcomes. GAO-01-288. Washington, D.C.: March 8, 2001.

GAO. Best Practices: A More Constructive Test Approach Is Key to Better Weapon System Outcomes. GAO/NSIAD-00-199. Washington, D.C.: July 31, 2000.

GAO. Executive Guide: Creating Value Through World-class Financial Management. GAO/AIMD-00-134. Washington, D.C.: April 2000.

GAO. Defense Acquisition: Best Commercial Practices Can Improve Program Outcomes. GAO/T-NSIAD-99-116. Washington, D.C.: March 17, 1999.

GAO. Executive Guide: Leading Practices in Capital Decision-Making. GAO/AIMD-99-32. Washington, D.C.: December 1998.

GAO. Best Practices: DOD Can Help Suppliers Contribute More to Weapon System Programs. GAO/NSIAD-98-87. Washington, D.C.: March 17, 1998.

GAO. Budget Issues: Budgeting for Capital. GAO/T-AIMD-98-99. Washington, D.C.: March 6, 1998

GAO. Best Practices: Successful Application to Weapon Acquisitions Requires Changes in DOD's Environment. GAO/NSIAD-98-56. Washington, D.C.: February 24, 1998.

Joint Financial Management Improvement Program. Framework for Federal Financial Management Systems. FFMSR-0. January 1995. 


\section{Human CaPital}

GAO. Human Capital: Principles, Criteria, and Processes for Governmentwide Federal Human Capital Reform. GAO-05-69SP. Washington, D.C.: December 1, 2004.

GAO. Posthearing Questions Related to Assessing Progress in Human Capital Management. GAO-04-1072R. Washington, D.C.: September 3, 2004.

GAO. Human Capital: Building on the Current Momentum to Transform the Federal Government. GAO-04-976T. Washington, D.C.: July 20, 2004.

GAO. Human Capital: Increasing Agencies' Use of New Hiring Flexibilities. GAO-04-959T. Washington, D.C.: July 13, 2004.

GAO. Human Capital: Key Practices to Increasing Federal Telework. GAO-04-950T. Washington, D.C.: July 8, 2004.

GAO. Human Capital: Selected Agencies' Use of Alternative Service Delivery Options for Human Capital Activities. GAO-04-679. Washington, D.C.: June 25, 2004.

GAO. Posthearing Questions Related to Agencies' Implementation of the Chief Human Capital Officers (CHCO) Act. GAO-04-897R. Washington, D.C.: June 18, 2004.

GAO. Human Capital: Additional Collaboration Between OPM and Agencies Is Key to Improved Federal Hiring. GAO-04-797. Washington, D.C.: June 7, 2004.

GAO. Human Capital: Status of Efforts to Improve Federal Hiring. GAO-04-796T. Washington, D.C.: June 7, 2004.

GAO. Highlights of a GAO Forum: Workforce Challenges and Opportunities For the 21st Century: Changing Labor Force Dynamics and the Role of Government Polices. GAO-04-845SP. Washington, D.C.: June 2004.

GAO. Human Capital: Senior Executive Performance Management Can Be Significantly Strengthened to Achieve Results. GAO-04-614. Washington, D.C.: May 26, 2004.

GAO. Human Capital: Observations on Agencies' Implementation of the Chief Human Capital Officers Act. GAO-04-800T. Washington, D.C.: May 18, 2004.

GAO. Human Capital: A Guide for Assessing Strategic Training and Development Efforts in the Federal Government. GAO-04-546G. Washington, D.C.: March 2004. 
GAO. Human Capital: Selected Agencies' Experiences and Lessons Learned in Designing Training and Development Programs. GAO-04-291. Washington, D.C.: January 30, 2004.

GAO. Human Capital: Implementing Pay for Performance at Selected Personnel Demonstration Projects. GAO-04-83. Washington, D.C.: January 23, 2004.

GAO. Acquisition Management: Agencies Can Improve Training on New Initiatives. GAO-03-281. Washington, D.C.: January 15, 2003.

GAO. Acquisition Workforce: Status of Agency Efforts to Address Future Needs. GAO-03-55. Washington, D.C.: December 18, 2002.

GAO. Human Capital: Effective Use of Flexibilities Can Assist Agencies in Managing Their Workforces. GAO-03-2. Washington, D.C.: December 6, 2002.

GAO. Acquisition Workforce: Department of Defense's Plans to Address Workforce Size and Structure Challenges. GAO-02-630. Washington, D.C.: April 30, 2002.

GAO. A Model of Strategic Human Capital Management. GAO-02-373SP. Washington, D.C.: March 15, 2002.

U.S. Office of Personnel Management. Human Resources Flexibilities and Authorities in the Federal Government. Washington, D.C.: July 25, 2001.

GAO. Managing For Results: Emerging Benefits From Selected Agencies' Use of Performance Agreements. GAO-01-115. Washington, D.C.: October 30, 2000.

GAO. Best Practices: DOD Training Can Do More to Help Weapon System Programs Implement Best Practices. GAO/NSIAD-99-206. Washington, D.C.: August 16, 1999.

\section{Knowledge and Information Management}

GAO. Defense Acquisitions: Better Information Could Improve Visibility over Adjustments to DOD's Research and Development Funds. GAO-04-944. Washington, D.C.: September 17, 2004.

GAO. Best Practices: Using Spend Analysis to Help Agencies Take a More Strategic Approach to Procurement. GAO-04-870. Washington, D.C.: September 16, 2004.

GAO. Information Technology: DOD's Acquisition Policies and Guidance Need to Incorporate Additional Best Practices and Controls. GAO-04-722. Washington, D.C.: July 30, 2004. 
GAO. Acquisition/Financial Systems Interface Requirements: Checklist for Reviewing Systems under the Federal Financial Management Improvement Act. GAO-04-650G. Washington, D.C.: June 2004.

GAO. Defense Acquisitions: Knowledge of Software Suppliers Needed to Manage Risks. GAO-04-678. Washington, D.C.: May 25, 2004.

GAO. Information Technology Investment Management: A Framework for Assessing and Improving Process Maturity. GAO-04-394G. Washington, D.C.: March 2004, Version 1.1.

GAO. Financial Management: Some DOD Contractors Abuse the Federal Tax System with Little Consequence. GAO-04-95. Washington, D.C.: February 12, 2004.

GAO. Best Practices: Using a Knowledge-Based Approach to Improve Weapon Acquisition. GAO-04-386SP. Washington, D.C.: January 2004.

GAO. Best Practices: Improved Knowledge of DOD Service Contracts Could Reveal Significant Savings. GAO-03-661. Washington, D.C.: June 9, 2003.

GAO. Contracting for Information Technology Services. GAO-03-384R. Washington, D.C.: February 14, 2003.

GAO. Assessing the Reliability of Computer-Processed Data. GAO-03-273G. Washington, D.C.: October 2002, External Version 1.

Joint Financial Management Improvement Program. Acquisition/Financial Systems Interface Requirements. JFMIP-SR-02-02. June 2002.

Joint Financial Management Improvement Program. Core Financial System Requirements. JFMIP-SR-02-01. November 2001.

GAO. Executive Guide: Creating Value Through World-class Financial Management. GAO/AIMD-00-134. Washington, D.C.: April 2000.

GAO. Federal Information System Controls Audit Manual, Volume I - Financial Statement Audits. GAO/AIMD-12.19.6. Washington, D.C.: January 1999.

GAO. Assessing Risks and Returns: A Guide for Evaluating Federal Agencies' IT Investment Decision-making. GAO/AIMD-10.1.13. Washington, D.C.: February 1997.

GAO. Information Technology Investment: Agencies Can Improve Performance, Reduce Costs, and Minimize Risks. GAO/AIMD-96-64. Washington, D.C.: September 30, 1996.

Joint Financial Management Improvement Program. Framework for Federal Financial Management Systems. FFMSR-0. January 1995. 


\section{GAO's Mission}

The Government Accountability Office, the audit, evaluation and investigative arm of Congress, exists to support Congress in meeting its constitutional responsibilities and to help improve the performance and accountability of the federal government for the American people. GAO examines the use of public funds; evaluates federal programs and policies; and provides analyses, recommendations, and other assistance to help Congress make informed oversight, policy, and funding decisions. GAO's commitment to good government is reflected in its core values of accountability, integrity, and reliability.

Obtaining Copies of GAO Reports and Testimony
The fastest and easiest way to obtain copies of GAO documents at no cost is through GAO's Web site (www.gao.gov). Each weekday, GAO posts newly released reports, testimony, and correspondence on its Web site. To have GAO e-mail you a list of newly posted products every afternoon, go to www.gao.gov and select "Subscribe to Updates."

\section{Order by Mail or Phone}

The first copy of each printed report is free. Additional copies are $\$ 2$ each. A check or money order should be made out to the Superintendent of Documents. GAO also accepts VISA and Mastercard. Orders for 100 or more copies mailed to a single address are discounted 25 percent. Orders should be sent to:

U.S. Government Accountability Office

441 G Street NW, Room LM

Washington, D.C. 20548

To order by Phone: Voice: (202) 512-6000

TDD: (202) 512-2537

Fax: (202) 512-6061

To Report Fraud,

Waste, and Abuse in Federal Programs

Congressional Relations

Public Affairs
Contact:

Web site: www.gao.gov/fraudnet/fraudnet.htm

E-mail: fraudnet@gao.gov

Automated answering system: (800) 424-5454 or (202) 512-7470

Gloria Jarmon, Managing Director, JarmonG@gao.gov (202) 512-4400

U.S. Government Accountability Office, 441 G Street NW, Room 7125

Washington, D.C. 20548

Paul Anderson, Managing Director, AndersonP1@gao.gov (202) 512-4800

U.S. Government Accountability Office, 441 G Street NW, Room 7149

Washington, D.C. 20548 

GA0-05-218G

Download this publication from GAO's Web site:

www.gao.gov/cgi-bin/ getrpt?GA0-05-218G 